\title{
Erratum: Taxonomic Characterization and Short-Chain Fatty Acids Production of the Obese Microbiota
}

\section{OPEN ACCESS}

Approved by:

Frontiers Editorial Office, Frontiers Media SA, Switzerland

*Correspondence: Frontiers Production Office production.office@frontiersin.org

Specialty section: This article was submitted to Microbiome in Health and Disease, a section of the journal

Frontiers in Cellular and Infection Microbiology

Received: 22 September 2021 Accepted: 22 September 2021

Published: 12 October 2021

Citation: Frontiers Production Office (2021) Erratum: Taxonomic Characterization and Short-Chain Fatty Acids Production of the Obese Microbiota. Front. Cell. Infect. Microbiol. 11:781260.

doi: 10.3389/fcimb.2021.781260

\section{Frontiers Production Office ${ }^{*}$}

Frontiers Media SA, Lausanne, Switzerland

Keywords: diversity, microbiota, obesity, metabolic activity, short-chain fatty acids, in vitro incubations

\section{An Erratum on}

Taxonomic Characterization and Short-Chain Fatty Acids Production of the Obese Microbiota By Martinez-Cuesta MC, del Campo R, Garriga-Garcia M, Peláaz C and Requena T (2021). Front. Cell. Infect. Microbiol. 11:598093. doi: 10.3389/fcimb.2021.598093

Due to a production error, there was a mistake in Figures 5, 6, and 7 as published. Figure 5 should contain parts A and B, rather than just part A. What was published as Figure 6 should be Figure 5B. What was published as Figure 7 should be Figure 6. Figure 7 was subsequently left out of the article. The corrected Figures 5, 6, and 7 appear below.

The publisher apologizes for this mistake.

The original version of this article has been updated.

Copyright (c) 2021 Frontiers Production Office. This is an open-access article distributed under the terms of the Creative Commons Attribution License (CC BY). The use, distribution or reproduction in other forums is permitted, provided the original author(s) and the copyright owner(s) are credited and that the original publication in this journal is cited, in accordance with accepted academic practice. No use, distribution or reproduction is permitted which does not comply with these terms. 

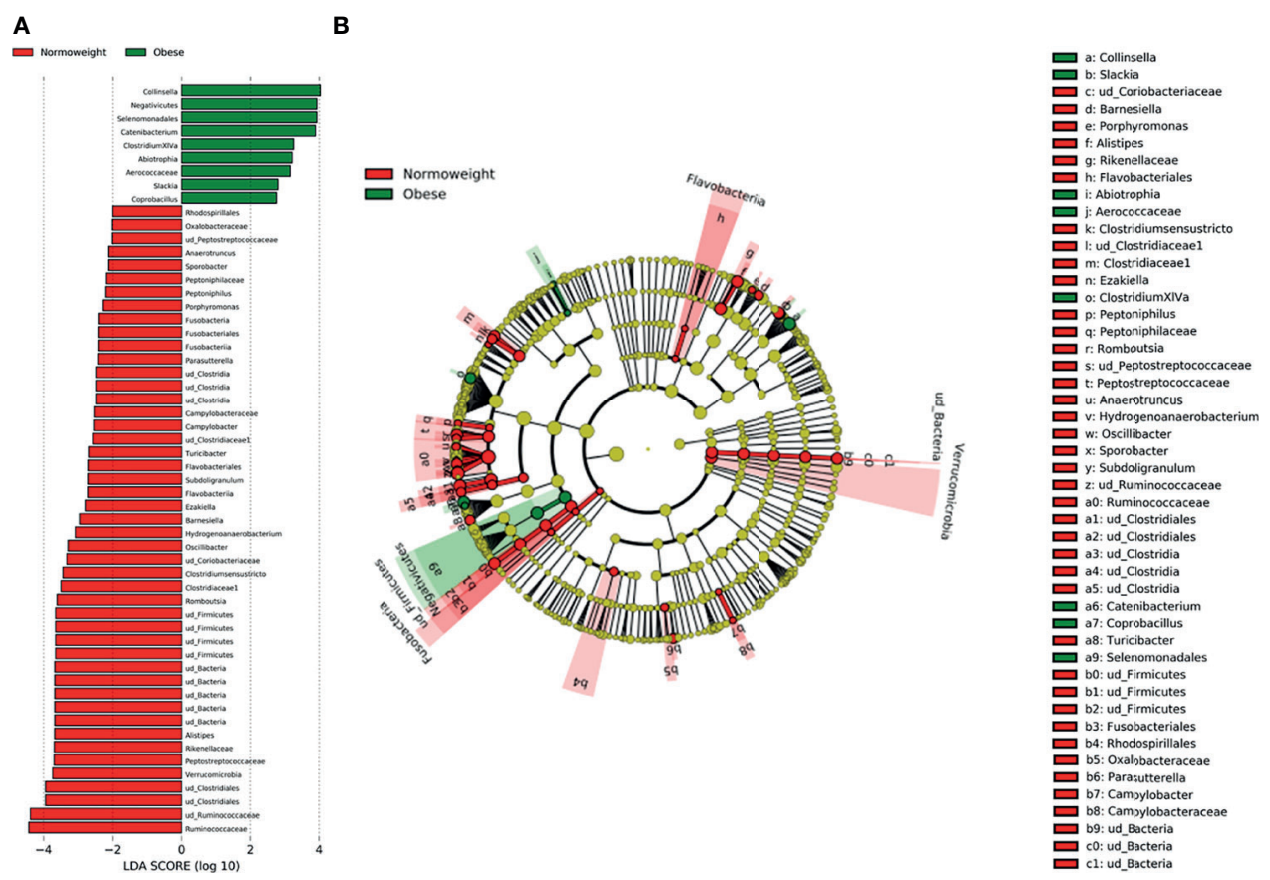

FIGURE 5 | Characterization of microbiomes by LEfSe analysis and LDA. (A) Histogram of the LDA scores (log10) computed for features with differential abundance in normal weight $(\mathrm{N})$ and obese $(\mathrm{O})$ subjects. (B) Cladograms showing the significant differences of gut microbiota composition in normoweight $(\mathrm{N})$ and obese $(\mathrm{O})$ subjects.

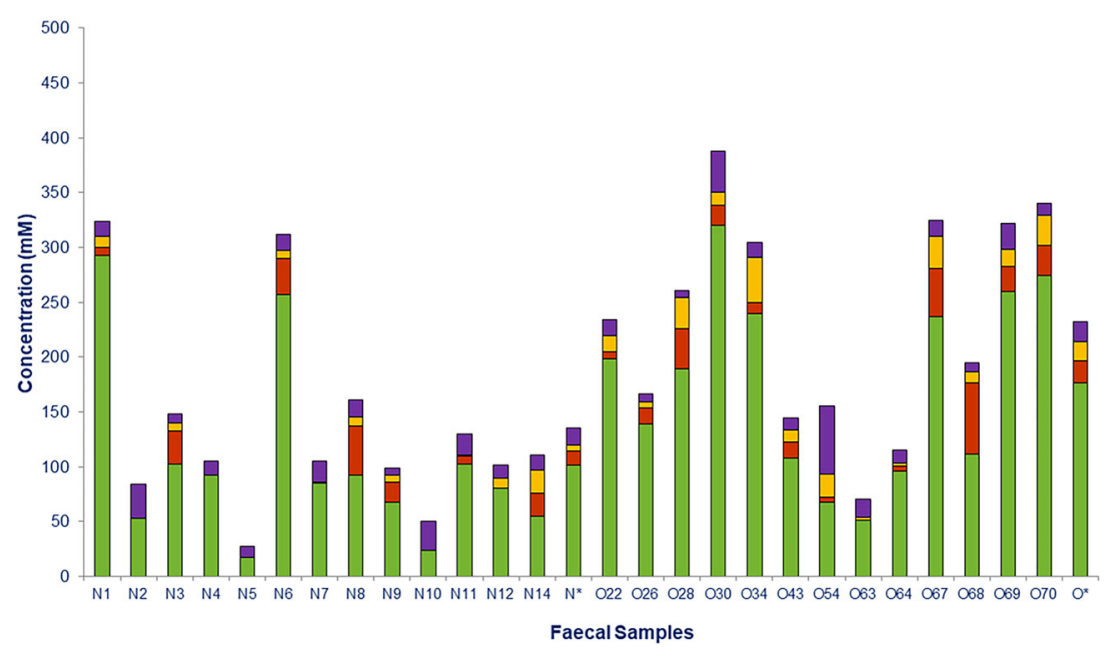

FIGURE 6 | Short chain fatty acids (SCFAs) and lactate measured in fecal samples from normoweight $(\mathrm{N})$ and obese $(\mathrm{O})$ individuals: acetate ( $)$ ), propionate ( $\mathrm{\square})$, butyrate $(\square)$, and lactate $(\square)$. The column $\left(^{*}\right)$ represents the median value of each group. 


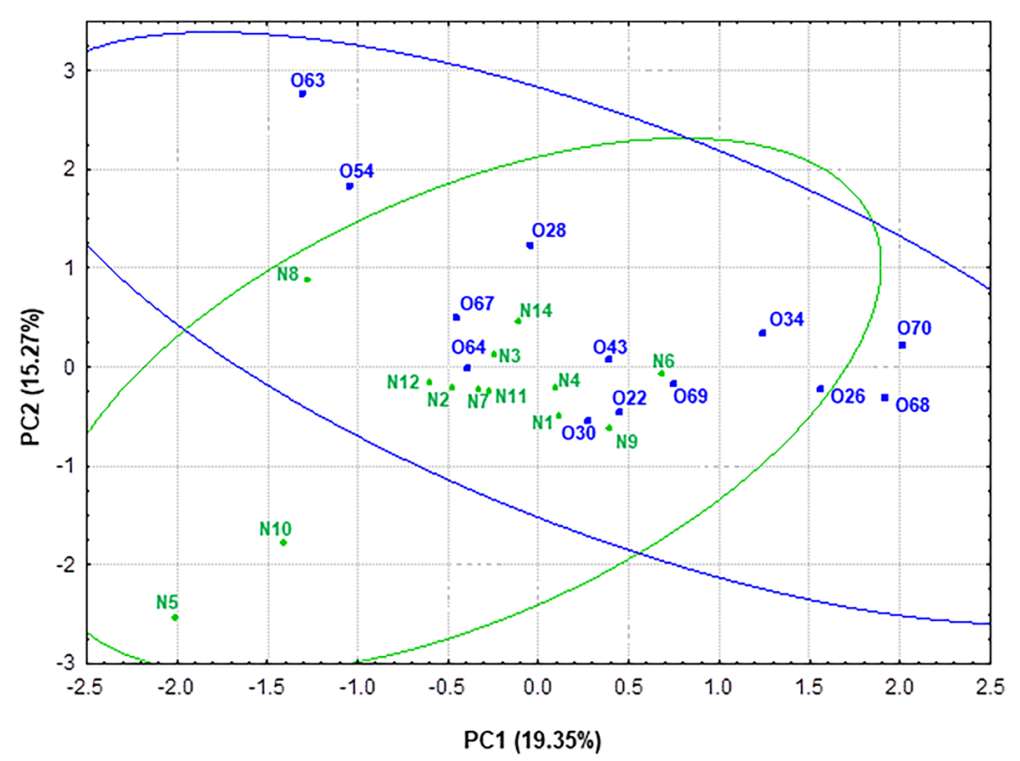

FIGURE 7 | Representation of the samples from normoweight $(\mathrm{N})$ and obese $(\mathrm{O})$ individuals in the plane defined by the two first components (PC1 and PC2) resulting from a PCA that takes into account both genera taxonomic groups and the metabolic activity-SCFAs and ammonium-data. 